\title{
Determinants of off-farm participation decision of farm households in Ethiopia
}

\author{
AD Beyene ${ }^{1}$
}

\begin{abstract}
This study analyses the determinants of off-farm work participation decisions of farm households in Ethiopia. A bivariate probit model is applied to account for the simultaneity of participation decisions of both male and female members of farm households. The results of the analysis show that human capital variables such as health and training on non-farm activities have a positive effect on the off-farm participation decisions of male members of farm households. The education status of the head has no significant impact on the participation decisions of the members of the family as most of the off-farm activities do not require formal education. The availability of credit and transfer income is the other factors that have a positive impact on the decisions of male members to participate in off-farm activities. The effects of family and farm characteristics are also analysed. Finally, policies that aim to increase the off-farm work participation decisions of family members should take into consideration the difference in responses to the various factors that affect the off-farm work decisions of male and female members of farm households.
\end{abstract}

Keywords: Off-farm; participation; bivariate; rural; Ethiopia

\section{Introduction}

\subsection{Background}

Ethiopia is a rural and agrarian society where nearly $85 \%$ of the population is directly dependent on agriculture and livestock for their livelihood. Agriculture is the mainstay of the economy. It accounts for about $50 \%$ of the GDP and $90 \%$ of the total foreign exchange earnings. The main types of farming activities are crop production, livestock husbandry and mixed farming. Mixed farming is the dominant type of farming system and includes both crop production and animal husbandry. The dominant type of farm input is labour and most of the farm labor comes from family members.

\footnotetext{
${ }^{1}$ Department of Agricultural Economics, Extension and Rural Development, Centre for Environmental Economics and Policy in Africa (CEEPA), University of Pretoria, South Africa. E-mail: abebed2002@yahoo.co.uk.
} 
Despite the different measures taken by governments, the national economy still relies on the agricultural sector which is characterised by low labor productivity, a declining farm size (an average of one hectare per household) and subsistence farming, soil degradation, inadequate and variable rainfall, tenure insecurity, weak agricultural research base and extension system, lack of financial services, imperfect agricultural markets and poor infrastructure (Degefe \& Nega, 1999).

During the military government known as Derg various public institutions like the Rural Technology Promotion Department (RTPD) of the Ministry of Agriculture, the Handicraft and Small Industries Development Agency (HASIDA) of the Ministry of Industry and the Adult Training Centres of the Ministry of Education were trying to promote the non-farm sector. These institutions, however, were not successful because of policy and institutional problems from the beginning. Each agency or organisation tends to work in isolation and there was no single focal point to co-ordinate and harmonise the support of the rural non-farm sector for greater effectiveness. After the downfall of the Derg regime, the Ethiopian People's Revolutionary Democratic Front (EPRDF) changed the centrally planned economy to a market economy by liberalising the economy and encouraging private sector participation. The reform process has negatively affected the institutions set to promote the non-farm sector under the previous government.

In rural areas of developing countries in general and Ethiopia in particular, labor market participation is the major source of income for many landless and small farm households. In spite of the high potential of the non-farm sector in generating employment, they are not covered by government policies and strategies. Rural development policies aiming at promoting the farm/nonfarm linkages should consider the role of the non-farm sector. Thus identifying the factors that affect the off-farm participation decisions of farm households is necessary if there is a need to make households diversify the ways in which they gain their livelihood. However, studies on the off-farm participation decision of Ethiopian farm households are limited. Moreover, the available literature does not consider the difference in the response by the male and female members of the family to the different personal, locational and farm characteristics. Therefore, the objective of this study is to investigate the determinants of off-farm labor participation decisions of the male and female members of farm households in Ethiopia.

The rest of the paper is organised as follows. The next section reviews related works in off-farm work participation. Section three is the data source and methodology and explains the econometric model specification used for 
analysing the data. Section four deals with the nature of rural off-farm employment in Ethiopia. The results of the empirical analysis are discussed in section five. The last section is the summary and conclusion.

\section{Literature review}

The literature dealing with off-farm employment has focused on factors affecting participation in off-farm work and off-farm labor supply. A significant part of this aspect of off-farm activities has not yet been researched in developing countries in general and Ethiopia in particular. Very few studies have empirically considered the factors that influence the decisions of rural farm households in sub-Saharan Africa to participate in non-farm production and labor supply off-farm (Reardon, 1997, cited by Abdulai \& Delgado, 1999). Previous studies on the rural non farm economy in Africa have concentrated on the characteristics of micro-enterprises in rural areas, quantifying the share of non-farm in total income and employment to show the range of roles played by non-farm activities in the household economy (Abdulai \& Delgado, 1999).

Benjamin and Guyomard (1994), in their study of off-farm work decisions of French agricultural households, show that the main effects on off-farm labour market participation decisions of both members (husband and wife) are: -

- Higher general education was reflected in higher off-farm labor market participation of both operators and spouses.

- The younger wives are the more likely to work off-farm.

- The number of children decreases the wife's participation in the off-farm labor market, i.e. increases her reservation wage, and

- Farm operators seem to be more responsive to farm characteristics than wives.

De Janvry and Sadoulet (2001) studied the role of off-farm activities in rural households in Mexico. The result shows that participation in off farm activities helps reduce poverty and contributes to greater equality in the distribution of income. Results of the Multinomial Estimation Method (where no participation in off-farm work is the choice comparison) show that education, ethnic origin and regional availability of off-farm employment are found to affect participation in off-farm activities. Education helps the farm households in the study area to participate in the more remunerative off-farm activities. A study by Corpal and Reardon (2001) also shows that the effect of education is found to be different depending on the type of off-farm activities. Similarly, land scarcity and access to roads have an effect on the participation decision in non farm employment. A study undertaken in four districts of Pakistan by 
Fafchamps and Quisumbing (1997) indicated that education raises off-farm productivity and induces rural Pakistan households to shift labor resources from farm to off-farm activities. One additional year of schooling for all adult males raises household incomes by $8.9 \%$. The other human capital variable, health, has also a positive effect for males but the result is not significant for females in rural Pakistan.

Abdulai and Delgado (1999) jointly estimated the determinants of the decision of husbands and wives to participate in cash- income-oriented non-farm work in Northern Ghana by using a bivariate probit model. The result of the analysis suggests that the variable age has a positive effect on the probability of labor supply to the non-farm sector at younger ages and at older ages the probability of participating in non-farm work decreases as age increases. Human capital, as embodied in education and experience, is essential in increasing non-farm earnings and time allocation of rural families and to diversify the rural economy away from agriculture. A husband or wife who had more schooling (as measured by years of schooling) had a significantly higher probability of engaging in non-farm activities. The other variables nonlabour income and distance to the regional capital are found to have a negative influence on the participation decisions of farm households. Unlike other studies the presence of children had no significant effect on the participation decision of women in non-farm work and on the labor supply of husbands and wives. This is similar with findings of Rosenzweig (1980) and Skoufias (1994). Jacoby (1993) also indicated that the number of children 5 years old and younger does not lessen women's hours worked, which includes housework, though not child care per se. But a well-developed infrastructure and population density had positive significant effects on the probability of non-farm work by both males and females.

The Ministry of Labor and Social Affairs (MOLSA) in Ethiopia undertook a survey of the Agricultural Wage Employment and Rural Non-Farm Employment in 1997. The result of the logit regression analysis shows that the probability of working for wage is lower for literate households than illiterate ones. The reason is that casual labor is generally perceived as a low status work by the public and more so by educated people. Similarly, Woldehanna (2000) tried to determine the impact of traditional and modern education on the supply of labor for off-farm wage employment in Tigray and reached the same result (negative sign). He argued that higher education increases the productivity of the individual on the farm or in the household more than it increases the productivity in off-farm employment or off-farm employment in the rural areas of Tigray may not require education at all and hence there is no special demand in the labor market for relatively educated farm households. 
On the other hand, a study carried out by Gebre Egziaber (2000) in two Woredas $^{2}$ of SNNP revealed that education is one of the effective instruments in promoting non-farm activities in rural areas. His research also shows that farmers with more farm resources are less attracted to non-farm activities.

Demeke and Regassa (1996) studied non-farm activities in North Shoa and concluded that education has a stronger impact in the vicinity of urban areas. ${ }^{3}$ However, in the more remote areas, it may have very little to contribute. The variable age has a negative influence in these areas. The share of non-farm income is higher for the younger age group than the older farmers. The results also show that yield is negatively related to participation in non-farm activities. In contrast to other studies, land size is found to have a positive influence on non-farm employment. They also concluded that female-headed households are not markedly disadvantaged with respect to non-farm earnings.

In general the limited literature sources about Ethiopia shows that either a simple descriptive or a probit or logit model is used to analyse the factors that affect the off-farm participation decision of farm households, but this makes the results inconclusive. This study uses a bivariate probit model that takes into account the simultaneity of both male and female participation decision. Moreover, no effort was made to see the impact of male and female members of the family separately in their participation decision at country level. That is why it is necessary to pursue the analysis empirically.

\section{Data source and methodology}

\subsection{The data}

The data source for this study is the 1999 Ethiopian Rural Household Survey conducted by the Department of Economics of Addis Ababa University in collaboration with the USAID. After the downfall of the Derg regime in 1991, EPRDF divided the country into nine regions and two administrative councils. Namely, Tigray, Afar, Amhara, Oromiya, Somali, Benishangul-Gumuz, Southern Nations, Nationalities and Peoples' region (SNNP), Gambella, Harari, Addis Ababa and Dire Dawa Administrative council. A total of 18 rural peasant associations were selected from four administrative regions. These are Tigray, Amhara, Oromiya, and SNNP. These regions represent around $96.7 \& 92 \%$ of the rural \& total population of the country respectively (CSA, 1999a). These sites were chosen in such a way that they could represent

\footnotetext{
${ }^{2}$ Woreda is a name given to the local administrative unit for a district.

${ }^{3}$ The dependent variable is defined as the ratio of non-farm income to farm income (cash).
} 
the socioeconomic and agro-ecological diversity of the rural areas. From the 18 peasant associations a total of 1681 farm households were selected randomly.

\subsection{Econometric model specification}

Econometric models are specified to examine the off-farm work participation decision of male and female members of farm households. Separate labor participation models were estimated for males and females.

The neoclassical farm household model predicted that a farm household chooses to work either on the farm or off-farm depending on the marginal return from farm and off-farm labor (Singh et al., 1986). For an individual, the action for off-farm participation is based on the comparison of the market wage rate and the reservation wage. The reservation wage is the marginal value of time when none is allocated to off-farm work. An individual will participate in off-farm work when the reservation wage is lower than the market wage (Benjamin \& Guyomard, 1994).

The reservation wage for off-farm work of $i$ is the marginal value of his/her time when all of it is allocated to farm labor and home time. Accordingly, the reservation and off-farm wage equations can be specified as follows:

$$
\begin{aligned}
& W^{r i}=X_{r}^{l} B_{i r}+e_{i r} \\
& W^{i}=X_{i}^{l} B_{i}+e_{i}
\end{aligned}
$$

Where: $\quad X_{r}^{l}$ and $X_{i}^{l}$ represent a vector of explanatory variables.

$B_{i r}$ and $B_{i}$ are estimated coefficients, and

$W^{i}$ is the market wage rate

$W^{r i}$ is the reservation wage

$e_{i r}$ and $e_{i}$ are the random disturbance terms.

The decision of male and female members of a farm household whether or not to participate in the off-farm labor market is then modelled as a binary probit model which takes in to account the simultaneity of both participation decisions. We define then a binary variable $D_{i}$ which equals 1 if member $i$ works off-farm, zero otherwise.

$$
\begin{aligned}
D_{i}= & \left\{\begin{array}{l}
1 \text { if } \\
0 \text { otherwise or } W^{r i} \geq W^{i}
\end{array}\right. \\
& P\left(D_{i}=1\right)=P\left(W^{i} \succ W^{r i}\right)=P\left(W^{i}>X_{r}^{l} B_{i r}+e_{i r}\right)
\end{aligned}
$$

Where the variables and coefficients are defined above. 
Therefore, the probability that the male and female members of a farm household work off-farm depends on their reservation wage $\left(W^{r i}\right)$ relative to the market wage rate net of commuting costs $\left(W^{i}\right)$. Variables that raise the reservation wage reduce the probability of off-farm work, and variables that raise the off-farm wage offer increase the probability of off-farm work. For variables that raise both the reservation wage and wage offer, the net effect on the probability of off-farm work is a priori uncertain. Estimates of these participation equations provide information about the marginal effects of exogenous variables on the probability of an individual participating in offfarm work.

\section{Off-farm employment in Ethiopia}

\subsection{The nature of off-farm employment $t^{4}$}

Non-farm activities have a great potential to provide employment and additional incomes during the slack season to rural households. In addition, given rising population pressure on agricultural land which results in a decline in land holding per individual, off-farm activities can provide alternative employment. Despite their great potential, rural non-agricultural activities account for less than 3\% of the rural labor force (CSA, 1999b).

Compared to other African countries, the proportion of the rural labor force engaged in non-farm activities in Ethiopia is too low. According to the International Labor Organization (1993), in Ghana for instance $26.7 \%$ of the rural workers were engaged in rural non-farm activities, $15 \%$ in Sierra Leone and an average ranging from 10 to $20 \%$ in sub-Saharan Africa. According to this report the importance of the rural non-farm activities in Ethiopia is understated because of the narrow definition by the Central Statistical Authority, and the Ethiopian definition of urban areas as towns of 2000 inhabitants or more compared to the UN definition, which uses 20,000 people as the cut-off point.

Farmers in Ethiopia are engaged in both self-employment and wage employment. ${ }^{5}$ The descriptive analysis of the data shows that about $43 \%$ of the total farm households are self-employed. Among the major activities are trades in grain/general trade $(27.4 \%)$, making and selling firewood, dung cakes, charcoal $(25.2 \%)$, weaving/spinning $(6.8 \%)$, collecting and/or selling

\footnotetext{
${ }^{4}$ Off-farm employment refers to employment in activities not on his/her farm. It includes employment on another farmer's farm. Non-farm employment refers to employment not related to farming activities.

${ }^{5}$ The different types of off-farm activities (self- and wage employment) are indicated in Appendix 1. Here, offfarm wage employment describes those households that are working off their land against payment in cash or in kind.
} 
straw $(9 \%)$, and trade in livestock/livestock products (8.12\%). Other activities are handicrafts, making and selling of farm implements, broker, selling araki, bakery, salt trade, shuriba sira, pottery, etc. ${ }^{6}$

About $25.3 \%$ of the sample households reported that they participate in wage employment. Among these households $38.8 \%$ participate in food-for-work programs. The other types of wage employment, in terms of their importance, are farm workers for pay $(24.0 \%)$, unskilled workers $(15.5 \%)$, and labourers (skilled i.e. builders, thatchers, etc. 9.1\%). Others are domestic servants, soldiers, professionals, etc. The wage rate per day varies by region and type of activity. It is relatively higher in regions such as Tigray and Oromiya than in Amhara and SNNP (MOLSA, 1997). The overall average off-farm wage rate for male members of the family is 0.73 birr $^{7}$ per hour, and for female members is 0.68 birr per hour. Most of the farmers are employed in government organisations $(30.9 \%)$, small farmers $(28.2 \%)$, and non-governmental organisations $(24.4 \%)$. Other employers of farmers include commercial farmers $(4.2 \%)$ and urban dwellers $(3.6 \%)$. Around $70 \%$ are working close to their village. Hence the participation of farmers in wage employment will increase if those opportunities are available in the vicinity of their village. Because of the seasonality of agriculture most of the farm households are engaged in wage employment on a daily basis $(48.9 \%)$ and on a temporary or contract basis $(42.4 \%)$. The rest are permanent workers.

\subsection{Income from off-farm activities}

Since production and productivity of the agricultural sector is low, farm households' income is not sufficient even to feed their families. Most of the sample farmers $(79 \%)$ are participating in off-farm activities mainly to supplement their agricultural income. Excess labor in the family and the seasonality of agriculture are the other key factors responsible for farmers to participate in off-farm activities. Large family in the rural house holds results in declining farm size which in turn results in low level of per capita production and hence less income. The seasonality of agriculture causes a farm family to have excess labour during the slack season, which induces them to engage in other non-farm activities.

\footnotetext{
${ }^{6}$ The figures do not include income obtained from renting out land, share cropped out land, and renting draft animals.

${ }^{7}$ Birr is the national currency of Ethiopia and the exchange rate is one USD equivalent to Birr 8.5678 (2002).
} 
Table 1: Reasons for participating in off-farm activities

\begin{tabular}{|l|c|l|c|}
\hline First reason & $\mathbf{\%}$ & Second reason & $\%$ \\
\hline Limited agricultural income & 79.3 & Large family & 27.2 \\
\hline Large family & 5.7 & Seasonal nature of agricultural labour & 18.2 \\
\hline $\begin{array}{l}\text { Favourable demand for goods and } \\
\text { services }\end{array}$ & 4.5 & Limited agricultural income & 15.7 \\
\hline Availability of off-farm opportunities & 3.2 & $\begin{array}{l}\text { Favourable demand for goods and } \\
\text { services }\end{array}$ & 14.7 \\
\hline Seasonal nature of agricultural labour & 2.5 & Availability of off-farm opportunities & 12.8 \\
\hline Other & 4.8 & Other & 11.4 \\
\hline
\end{tabular}

Source: own computation (Others include proximity to urban area, level of education, for household construction purpose, etc).

On average a farm household earns 615.9 birr per annum through off-farm activities. The mean annual income from self- and wage employment is 462.6 and 723.6 birr respectively. ${ }^{8}$ The proportion of income obtained from wage and self-employment is $43.4 \%$ and $56.6 \%$ of the total off-farm income respectively. Payment in these activities is made both in cash and in kind. More than $85 \%$ of the payment in kind is done in the form of wheat.

Around $90 \%$ of the off-farm participants responded that the income obtained from off farm activities is used for maintenance and own consumption. Very few farmers use the off farm income for investment in farm/land, to buy oxen and farm implements. Little is used for investment in non-farm activities and saving. This has an implication in that some measures have to be taken to promote the sector so that farmers will be able to get sufficient amount of income, which in turn is used, for investment in the farm.

\subsection{Women's participation in off-farm activities}

Since more than $85 \%$ of the total population of Ethiopia is dependent on agriculture, the performance of the sector relies on the labor of both genders. Rural women provide a substantial contribution to agricultural production. In addition to farming and home activities they also participate in non-farm activities. In the survey $22.6 \%$ of the household heads were females. On average $36.6 \%$ of the farm households have one or more female members participating in off-farm activities. The difference in the off-farm participation rate of females as compared to males is not significant. Females are participating in both wage and self-employment. Food-for-work is the major activity. They are also employed as farm workers and labourers in other activities. The average wage rate ranges from 0.02 to 1.68 birr per hour. In addition they are getting income by participating in self-employment activities like weaving/spinning, making and selling fire wood, dung cakes, charcoal,

\footnotetext{
${ }^{8}$ It is calculated for self and/or wage participants only.
} 
collecting and selling straw, pottery, general trade, income from share cropped out land, etc. Preparing food and local drinks such as araki, tella, injera, and dabbo are also common. ${ }^{9}$

However, females face different constraints in being involved in the sector. Activities like producing flour using the traditional sources, fuel and water collection, food preparation and childcare leave very little time for women to participate in income generating activities. Moreover, despite their substantial role in rural and agricultural development, ${ }^{10}$ they are gravely disadvantaged in terms of access to opportunities, such as credit, land, appropriate technology and health services, education, training, formal employment and at the decision-making level1111 (International Labor Organization, 1993). Female farmers, a special group of rural women, have remained almost invisible to policy makers, rural development practitioners and researchers (Aredo, 1994).

Generally, farmers are willing to work more hours if the different constraints for working off the farms are solved. For instance $44.6 \%$ of farm households reported that they have at least one member from their families who is interested in working longer hours. It is surprising that among those members of the farm households $39.4 \%$ are interested to work for wages the year round, $43.3 \%$ prefer to work at the end of the harvesting time, and $16.2 \%$ between weeding and harvest. Therefore, it is possible for farmers to get additional income by participating in off-farm work without affecting their own farming activities.

\section{Analysis of empirical results}

\subsection{Description of variables used in the analysis}

The variables used in the analysis and their theoretical expectations about the sign and magnitude of these variables on the participation decision in off-farm activities are discussed below. These variables were chosen based on the available literature.

Age of the household head and Age Square: this is a continuous variable that may represent general experience that increases the marginal value of time in each activity and other forces. At a younger age the probability of working off farm

\footnotetext{
${ }^{9}$ Araki: A local alcoholic drink that is mainly prepared by women. Tella: A local drink prepared by women. Injera: the traditional pancake-like bread usually prepared over an open fire. Dabbo: A local name given to bread.

${ }^{10}$ In Ethiopia, women play limited roles in agricultural production as compared to their counterparts in many countries in sub-Saharan Africa (Aredo, 1994).

${ }^{11}$ MOLSA (1997) also states that lack of credit, low sale prices, overlapping farm work and higher prices of raw materials are the major problems in handicraft activities
} 
will increase. At older ages the overall labor hours will diminish and the demand for leisure will increase. As a net result, a humped-shaped life cycle profile is expected.

Presence of children: A dummy variable assigned 1 if a child is present, zero otherwise. The presence of children aged five years or younger is expected to reduce the probability of working off-farm for female members of a farm household since they are more responsible than males. The probability of working off-farm for farm males might increase since the presence of children in the family requires the household to have additional income.

Health status: A dummy variable is assigned that represents whether any member of the farm household was unable to perform farm activities in the survey year. Its expected effect on the participation decision is negative.

Number of dependants: This variable refers to those members of farm households whose age is 5 years or younger and 65 years or above. A farm household with a majority of dependants is less likely to participate in offfarm work. On the other hand, when there are a larger number of dependants, the household has to raise more money and the marginal value of leisure will be decline, hence they will have to supply more labor off-farm. Therefore, the sign could not be determined a priori.

Sex of the household head: Since the male-headed households have more access to opportunities than female-headed households, the probability of working off-farm is expected to be positive for the former.

Education of the household head: This is a dummy variable classified according to ability to read and write, having had primary and secondary education. If the effects of human capital on off-farm wages out weigh the increase in the shadow value of labor on the farm, education is expected to have a positive effect on off-farm work decisions for both male and female members of the household (Lass et al., 1991).

Farm experience ${ }^{12}$ : This increases the value of the marginal value of farm work relative to the marginal value of off-farm work. So the probability of participation by both male and female members of farm household is expected to diminish.

\footnotetext{
12 The age of the household head minus years of schooling minus six years is taken as a proxy variable for farm experience.
} 
Non-farm training: This is a dummy variable representing whether any member of the farm household has undertaken any training in handicraft skills or not. It is expected to have a positive influence for off-farm work decisions by farmers.

Distance to the nearest market: The participation of farm family members in offfarm markets is affected not only by their willingness and ability to supply labor but also by the demand for this labor. A long distance (measured in kilometres) from the farm to the nearest market reduces the probability of working off the farm.

Size of cultivated land: We expect farmers with larger farms to participate less frequently in off-farm activities.

Number of draft animals owned: The possession of donkeys, mules, horses, and camels enables a farm household to participate in non-farm activities.

Credit: If members of farm households have access to credit then the probability of working off-farm is expected to increase.

Non-labour income: This variable has a positive effect on the marginal value of the non-work time and hence a negative effect on the participation decision of both family male and female members.

Location: This may affect the marginal value of farm or off-farm time. Dummy variables for each site are assigned in order to capture the effect of location on the off-farm work decision by members of farm households.

\subsection{Determinants of off-farm labour force participation}

The result of the bivariate probit estimation ${ }^{13}$ of the off-farm participation decision of farm households is presented in Table 3. The data definitions and the results of the descriptive analysis are found in Table 2.

In a survey data set such as the Ethiopian rural household survey a researcher should expect to encounter many problems. The problems of multicollinearity and heteroscedasticity are very common in cross-section data. The data should be cleared before it is used for purposes of analysis. Using the box plot graph and histogram identifies the outliers and the most frequent observation is assigned for each site so that details do not get lost.

\footnotetext{
${ }^{13}$ The econometric software Stata version 7 and SPSS were used to estimate the empirical models.
} 
The problem of multicollinearity can be detected by looking at the correlation matrix between the variables. But when there are more than two variables in the estimation of a model, looking at the correlation matrix may not be a true indicator of the problem of multicollinearity. Hence Condition Index ${ }^{14}$ is computed and if the value is greater than or equal to 20 , it is possible to expect that there could be a potential problem. The presence of heteroscedasticity is detected by using the Brush Pagan test. This problem is addressed by calculating the robust standard error for the probit model.

\section{Table 2: Descriptive statistics}

\begin{tabular}{|l|l|l|l|l|l|}
\hline Variable & Description & Mean & Std. Dev. & Min & Max \\
\hline age & age of the household head & 48.95 & 15.53 & 18 & 95 \\
\hline agesq & age square of the head & 2637.4 & 1644.3 & 324 & 9025 \\
\hline sex & sex of the head & 0.774 & 0.4184 & 0 & 1 \\
\hline drewr & $=1$ if the head can read and write & 0.1493 & 0.3565 & 0 & 1 \\
\hline dprimar & $=1$ if the head is primary & 0.2070 & 0.4053 & 0 & 1 \\
\hline dsecon & $=1$ if the head is secondary & 0.0363 & 0.1871 & 0 & 1 \\
\hline avscol & average school of the family & 1.65 & 2.089 & 1 & 12 \\
\hline dchild & $=1$ if child is present & 0.473 & 0.4994 & 0 & 1 \\
\hline dhealth & $=1$ if there is any disability in the & 0.3766 & 0.485 & 0 & 1 \\
& family & & & & \\
\hline numdep & number of dependants & 0.919 & 0.861 & 0 & 5 \\
\hline dhatrain & $=1$ if any training in handicrafts & 0.0333 & 0.18 & 0 & 1 \\
\hline nadrft & number of draft animals & 0.716 & 1.191 & 0 & 9 \\
\hline transfer & amount of transfer income & 98.91 & 888.10 & 0 & 26208 \\
\hline land & size of cultivated land & 1.07 & 1.046 & 0 & 8 \\
\hline farmexp & farming experience of the head & 41.6 & 16.68 & 5 & 89 \\
\hline cred & amount of credit & 124.99 & 271.52 & 0 & 5000 \\
\hline dist & distance from the nearest market & 7.5 & 5.37 & 0 & 20 \\
\hline
\end{tabular}

\footnotetext{
${ }^{14}$ Condition Index is the square root of the ratio of largest to smallest eigenvalues in the correlation matrix of the independent variables.
} 
Table 3: Participation in off-farm work activities

\begin{tabular}{|c|c|c|c|c|c|c|}
\hline \multirow{2}{*}{$\begin{array}{l}\text { Explanatory } \\
\text { variables }{ }^{15}\end{array}$} & \multicolumn{3}{|c|}{ Male } & \multicolumn{3}{|c|}{ Female } \\
\hline & Coeff. & $\mathbf{P}>|z|$ & $\begin{array}{l}\text { marginal } \\
\text { effects }\end{array}$ & Coeff. & $\mathbf{P}>|z|$ & $\begin{array}{l}\text { marginal } \\
\text { effects }\end{array}$ \\
\hline $\begin{array}{l}\text { Age (age of hh } \\
\text { head) }\end{array}$ & 0.0322 & 0.069 & 0.0071 & 0.0122 & 0.380 & 0.0044 \\
\hline $\begin{array}{l}\text { agesq (age } \\
\text { square) }\end{array}$ & -0.0003 & 0.058 & -0.0001 & -0.0002 & 0.240 & -0.0001 \\
\hline $\begin{array}{l}\text { sex (sex of the } \\
\text { head) }\end{array}$ & 0.5692 & 0.000 & 0.1044 & -0.1584 & 0.078 & -0.0615 \\
\hline $\begin{array}{l}\text { drewr (dummy } \\
\text { for read and } \\
\text { write) }\end{array}$ & 0.0553 & 0.620 & 0.0120 & -0.1197 & 0.229 & -0.0439 \\
\hline $\begin{array}{l}\text { dprimary } \\
\text { (dummy for } \\
\text { primary) }\end{array}$ & -0.0577 & 0.612 & -0.0124 & -0.0092 & 0.925 & -0.0036 \\
\hline $\begin{array}{l}\text { dsecon } \\
\text { (dummy for } \\
\text { secondary) }\end{array}$ & -0.0671 & 0.775 & -0.0117 & -0.3092 & 0.192 & -0.1086 \\
\hline $\begin{array}{l}\text { avscol (average } \\
\text { school of the } \\
\text { family) }\end{array}$ & 0.0348 & 0.162 & 0.0073 & -0.0029 & 0.897 & -0.0013 \\
\hline $\begin{array}{l}\text { dchild (dummy } \\
\text { for child) }\end{array}$ & 0.1764 & 0.169 & 0.0379 & 0.2217 & 0.048 & 0.0829 \\
\hline $\begin{array}{l}\text { nadrft (number } \\
\text { of draft } \\
\text { animals) }\end{array}$ & 0.0611 & 0.402 & 0.0135 & 0.1238 & 0.057 & 0.0465 \\
\hline $\begin{array}{l}\text { dhealth } \\
\text { (dummy for } \\
\text { health) }\end{array}$ & -0.1714 & 0.059 & -0.0375 & -0.0350 & 0.651 & -0.0142 \\
\hline $\begin{array}{l}\text { dhatrain (dumy } \\
\text { for handicraft } \\
\text { training) }\end{array}$ & 0.3985 & 0.051 & 0.1073 & 0.1667 & 0.378 & 0.0637 \\
\hline $\begin{array}{l}\text { numdep (no. of } \\
\text { dependants) }\end{array}$ & -0.0682 & 0.450 & -0.0157 & -0.1034 & 0.186 & -0.0394 \\
\hline $\begin{array}{l}\text { dist (distance to } \\
\text { the market) }\end{array}$ & 0.0625 & 0.000 & 0.0137 & 0.0160 & 0.177 & 0.0058 \\
\hline $\begin{array}{l}\text { lntsfer (transfer } \\
\text { income) }\end{array}$ & 0.0439 & 0.032 & 0.0097 & 0.0318 & 0.073 & 0.0119 \\
\hline $\begin{array}{l}\text { lnland (size of } \\
\text { land) }\end{array}$ & -0.0903 & 0.063 & -0.0197 & -0.1109 & 0.009 & -0.0420 \\
\hline $\begin{array}{l}\text { lncredt } \\
\text { (amount of } \\
\text { credit) }\end{array}$ & 0.0390 & 0.013 & 0.0085 & 0.0048 & 0.739 & 0.0017 \\
\hline _cons & -3.079 & 0.000 & & -0.6671 & 0.094 & \\
\hline
\end{tabular}

Wald test of rho $=0: \quad$ chi2 $(1)=12.3108$ Prob $>$ chi2 $=0.0005$

Wald chi2 $(64)=466.03$

Prob $>$ chi2 $=0.0000$

$\left({ }^{*}\right)$ For the dummy variables the marginal effect is the discrete change of dummy variable from 0 to 1 . $\mathrm{z}$ and $\mathrm{P}>|\mathrm{z}|$ are the test of the underlying coefficient being 0 .

${ }^{15}$ Site dummies are not provided for reasons of space. Farm experience is not included since it is highly correlated with age of the head. Note also that Intsfer, Inland, \& Incredt are in logarithm form. 
From Table 3 it is possible to draw conclusions about the magnitude and direction of each variable on the probability of working off-farm. The log likelihood ratio statistic was significant at the $1 \%$ level, suggesting that the independent variables taken together influence participation decisions. The correlation between the errors (rho) is significant which implies the decisions of both members of farm households are not independent.

The result of the analysis indicated that age and age square of the household head have the expected sign. The effect of age on participation decision is statistically significant only for male members (at 10\% level). For female members both are not statistically significant. At young ages, the probability of off-farm work participation of both members increase with age. Experience increases farm productivity and hence the reservation wage. It may also increase the off-farm productivity but the effect may not be as strong as that on the farm.

The effect of education level of the household head on the participation decision of members of the farm household is analysed by classifying it as read and write, ${ }^{16}$ primary education, and secondary education. To see the effect of level of education of the family, average schooling is also included as explanatory variable. ${ }^{17}$ The result suggests that education has no significant effect on the decision of farm households to participate in off-farm activities. The possible justification for this could be the nature of off-farm activities in the country. As stated in section four most of the off-farm activities especially for wage employment are food-for-work programs that do not require any education level. Off-farm activities performed by the farmers themselves are also more traditional which do not require any formal education. Woldehanna (2000) and MOLSA (1997) support this argument in their separate studies in Tigray and the Ethiopian case respectively.

The participation decision of female members of farm households does not seem to be dependent on the health status of family members. The effect is negative and significant at $10 \%$ for male members. Training in handicraft skills has a significant positive effect on off-farm participation by male members and is insignificant for that of female members. Farmers who had training in nonfarm activities are more likely to engage in either wage employment (such as masonry, carpentry, etc) or self-employment activities like weaving, carpentry, pottery, blacksmithing, etc. The policy implication is that institutions like HASIDA and the Rural Technology Centres should be supplemented and

\footnotetext{
${ }^{16}$ The dummy variable for read \& write refers to those who can read and write through traditional, religious or other non-formal education.

${ }^{17}$ The result remains the same if only average schooling is included in the participation equation (see Appendix 2).
} 
expand their activities in order to develop the skills required for farmers to work on their own or to be employed.

The influence of family characteristics is also analysed. The positive coefficient of sex shows that male members in male-headed households have a greater probability of working off-farm than female-headed households. Female members are less likely to participate in off-farm activities. This may be due to the influence of the head and cultural factors that females are naturally assigned to household activities. It is found that the presence of children in the family has a positive and significant impact on female members' participation decision but for male members the effect is not strong. The households may require additional income and that induces them to participate in off-farm activities (the income effect). The result is not consistent with most other studies in that it reduces the probability of working off-farm. The number of dependants in the family is negatively related to the participation decision of both members of a family, but the effect is found to be statistically insignificant.

The financial position of the household has also an impact on the decision of farm households. The results of the analysis shows that credit and transfer income have a positive effect on off- farm activities. A $10 \%$ increase in the amount of credit given to the household will increase the probability of working off-farm by 0.085 and that of transfer income by 0.097 for male members. For female members availability of credit has no significant effect on the probability of working off-farm. This may be because the households are less interested to borrow for female members' involvement in off-farm activities. But the probability of working off-farm increased by 0.12 for a $10 \%$ increase in transfer income.

The size of cultivated land has the expected sign and is statistically significantly different from zero. It increases the reservation wage of both male and female members of a farm household. This might also indicate that farmers involved in off-farm activities for push reason, i.e. because of shortage of land to support their livelihood. This result is consistent with other studies. The number of draft animals in the household has a positive impact on the probability of working off-farm. The result suggests that this variable is not a significant determinant for male members of farm households.

Theoretically, holding off-farm wage and other variables constant, the probability of working off-farm by the household members decreases as the market is located further away from their village. However, the result turned out to be different from what is expected in that it has a positive and 
significant influence on the male members' participation decision though it is not significant for female members. ${ }^{18}$

Location dummies are also included as explanatory variables to capture the opportunities and participation decision of farm households in different sites of the country. It is found that off -farm work participation is different in different sample sites. Relative to site Yetmen (D5), the reference site, the probability of working off-farm is relatively higher in drought-affected and food-deficit areas like Shumsha and Indibir. The rate of participation is relatively low in areas like Sirbana Goditi and Somodo that are relatively foodsurplus or self-sufficient areas.

\section{Summary and conclusions}

Agriculture is the backbone of the Ethiopian economy and the performance of the sector directly or indirectly affects the lives of many people. More than $85 \%$ of the labour force is engaged in agriculture. However, because of the natural and socioeconomic problems, Ethiopian farmers are suffering from instability of income. Low productivity of the sector is the major cause of unemployment and underemployment in the rural areas. Hence rural off-farm activities can play an important role in improving the well-being of the rural population. We have observed that $57.3 \%$ of the farm households have one or more members participating in off-farm activities (self-employment $43 \%$ and wage employment $25.3 \%$ ). Male and female family members participate in all these activities. Therefore, because of the importance of the sector to farm households and rural development, the factors or determinants of off-farm work decisions are analysed by using econometric models. This study attempts to investigate the impact of personal, household, and locational characteristics on the off-farm participation decisions of male and female members of farm households in Ethiopia.

The results of the empirical analysis show that of the human capital variables, education of the household head has no effect on the off-farm work decisions as most of the off-farm activities do not require formal education. The other human capital variable, health condition of the family, is obviously an important factor that affects the time allocation decision of the family. Even though training in non-farm activities have not been given due attention, its importance in the off-farm work decisions of farm households are supported by the analysis. Therefore, giving emphasis to the role of non-farm training by governmental and non-governmental organisations dealing with rural development will enable farmers to diversify their sources of income.

${ }^{18}$ When the site dummies are ignored the result was as expected. 
Farmers have financial constraints in being involved in off-farm activities. The development of rural micro-financial institutions serving the rural population will contribute to the promotion of the non-farm sector. The current policy of the government to expand the micro- financial institutions in rural areas will enable the farmers to diversify their sources of income and will contribute significantly to the overall poverty reduction in the country.

The effect of farm characteristics (farm size) also shows that farmers are participating in off-farm activities for push reasons. The small farm size forces them to look for other sources of income. Therefore, poor and landless households may be benefited from the sector. The off-farm participation behaviour of farmers is found to differ in different places in the country. It is higher in areas affected by drought and lower in relatively self-sufficient areas.

Finally, policies that aim in increasing the off-farm work participation decisions of family members should take into consideration the difference in response to the various factors that affect the off-farm work decisions of male and female members of farm households. Further research is required that tries to determine the off-farm work decisions of farm households in wage and self-employment activities separately. Moreover, studies that consider the demand side of the labor market together with the supply side will enable one to understand the full functioning of the rural labor market.

\section{Acknowledgements}

I would like to thank the Economics Department of Addis Ababa University for allowing me to use the Ethiopian rural household survey data.

\section{References}

Abdulai A \& Delgado CL (1999). Determinants of non-farm earnings of farmbased husbands and wives in Northern Ghana. American Journal of Agricultural Economics 81(1):117-130.

Aredo D (1994). Female-headed farm households in two contrasting regions in Ethiopia: access to and management of resources: Ethiopian Journal of Development Research 16(1):1-12.

Benjamin C \& Guyomard H (1994). Off-farm work decisions of French agricultural households. In: Caillavet F, Guromard H \& Litran R (eds). Agricultural household modeling and family economics. Amsterdam: Elsevier. 6585. 
Corpal L \& Reardon (2001). Rural non-farm incomes in Nicaragua. World Development 29(3):427-441.

CSA (1999a). Report on monthly average retail price of goods and services in rural areas, by kilil and zone. Statistical Bulletin 222, Addis Ababa, Ethiopia.

CSA (1999b). Statistical report on the 1999 National Labor Force Survey. Statistical Bulletin 225, Addis Ababa, Ethiopia.

Degefe B \& Nega B (1999). Annual report on the Ethiopian economy. EEA 1:78, Addis Ababa, Ethiopia.

De Janvry A \& Sadoulet E (2001). Income strategies among rural households in Mexico: the role of off-farm activities. World Development 29(3):467-480.

Demeke M \& Regassa T (1996). Non-farm activities in Ethiopia: the case of North Shoa. In: Kebede B \& Taddesse M (eds). The Ethiopian economy, poverty and poverty alleviation. Proceedings of the Fifth Annual Conference on the Ethiopian Economy, Addis Ababa, Ethiopia, December. 125-162.

Fafchamps M \& Quisumbing AR (1997). Human capital, productivity, and labor allocation in rural Pakistan. Department of Economics, Stanford University, Stanford, USA.

Gebre Egziaber T (2000). Non-farm activities and production decisions of farmers: the case of Damotgale and Kachabira woredas in southern region of Ethiopia. Social Science Research Report, Series No. 15, March. Addis Ababa, Ethiopia.

International Labor Organization (ILO) (1993). World Employment Program; Ethiopia towards sustained employment promotion: Jobs and Skills Programme for Africa (JASPA). Addis Ababa: ILO.

Jacoby H (1993). Shadow wages and peasant family labour supply: an econometric application to the Peruvian Sierra. Review of Economic Studies 60:903-922.

Lass DA, Findeis JL \& Hallberg MC (1991). Factors affecting the supply of off-farm labour: a review of empirical evidence. In: Hallberg MC, Findeis JL \& Lass DA (eds). Multiple job holding among farm families. Ames: Iowa State University Press. 239-262. 
MOLSA (1997). Agricultural wage employment and rural non-farm employment in Ethiopia: survey results. Addis Ababa: MOLSA.

Rosenzweig MR (1980). Neoclassical theory and the optimizing peasant: an econometric analysis of market family labour supply in a developing country. Quarterly Journal of Economics 94:31-55.

Singh I, Squire L \& Strauss J (eds) (1986). Agricultural household models: extensions, application, and policy. Baltimore: Johns Hopkins University Press.

Skoufias E (1994). Using shadow wages to estimate labour supply of agricultural households. American Journal of Agricultural Economics 76:215-227.

Woldehanna T (2000). Economic analysis and policy implications of farm and off-farm employment, a case study in Tigray Region of Ethiopia. Unpublished PhD dissertation, Wageningen University, Wageningen, The Netherlands. 


\section{Appendix 1: Types of activities}

1. Types of activities in self-employment

\begin{tabular}{|l|c|}
\hline \multicolumn{1}{|c|}{ Activity } & $\begin{array}{c}\text { Percentage } \\
(\mathbf{\%})\end{array}$ \\
\hline Weaving/spinning & 6.8 \\
\hline Milling & 0.81 \\
\hline Tailoring & 0.81 \\
\hline $\begin{array}{l}\text { Handicraft, making \& selling farm } \\
\text { implements }\end{array}$ & 1.95 \\
\hline Tannery & 1.14 \\
\hline $\begin{array}{l}\text { Making \& selling firewood, dung cakes, } \\
\text { charcoal }\end{array}$ & 25.2 \\
\hline Collecting and/or selling straw & 9 \\
\hline Shuruba sira (traditional hair dresser) & 6.3 \\
\hline Salt trade & 0.33 \\
\hline Trade in grain/general trade & 27.4 \\
\hline Trade in livestock/livestock prod. & 8.12 \\
\hline Traditional healer/religious teacher & 0.98 \\
\hline Transport (by pack animal) & 1.8 \\
\hline Basketry & 0.81 \\
\hline Pottery & 4.1 \\
\hline Shoe shinning & 0.65 \\
\hline Butcher & 0.33 \\
\hline Carving \& selling of stone & 1.14 \\
\hline Broker & 0.33 \\
\hline Barber & 0.16 \\
\hline Selling Araki & 0.49 \\
\hline Hair dresser (Shruba) & 0.33 \\
\hline Sale of land & 0.16 \\
\hline Making and selling malt & 0.16 \\
\hline Others & 0.64 \\
\hline Total & $\mathbf{1 0 0}$ \\
\hline
\end{tabular}

2. Type of wage employment

\begin{tabular}{|ll|}
\hline $\begin{array}{l}\text { Type of wage } \\
\text { employment }\end{array}$ & $\begin{array}{l}\text { Percentage } \\
(\mathbf{\%})\end{array}$ \\
\hline Farm worker (for pay) & 24.0 \\
\hline Professional & 2.5 \\
\hline Labourer & 9.1 \\
\hline Soldier & 0.4 \\
\hline Driver/mechanic & 1.1 \\
\hline Unskilled worker & 15.5 \\
\hline Domestic servant & 2.1 \\
\hline Food-for-work & 38.9 \\
\hline Religious worker & 0.2 \\
\hline Guard & 3.2 \\
\hline Broker & 0.2 \\
\hline Flour mill operator & 0.2 \\
\hline Others & 2.8 \\
\hline Total & $\mathbf{1 0 0}$ \\
\hline
\end{tabular}


Appendix 2: Determinants of off-farm work participation (including only average school attainment by the household members)

\begin{tabular}{|l|l|l|l|l|l|l|l|l}
\hline \multicolumn{9}{c}{ Male } \\
\hline
\end{tabular}

No significant difference was found when only the education level of the family members (average schooling) is included in the off- farm work participation equation. 